\title{
LXXVII. The ratio between uranium and radium in minerals. II
}

\section{Ruth Pirret B.Sc \& Frederick Soddy M.A. F.R.S.}

To cite this article: Ruth Pirret B.Sc \& Frederick Soddy M.A. F.R.S. (1911) LXXVII. The ratio between uranium and radium in minerals. II, Philosophical Magazine Series 6, 21:125, 652-658, DOI: $10.1080 / 14786440508637078$

To link to this article: http://dx.doi.org/10.1080/14786440508637078

曲 Published online: 21 Apr 2009.

Submit your article to this journal $\lceil\pi$

Џ Article views: 5

Q View related articles $\square$

Citing articles: 1 View citing articles 5 
Evidence is aiso given of a limit to the penetrating power of Röntgen radiation. Unless the laws of scattering somewhere break down, the lowest possible value for $\frac{\lambda}{\rho}$ is about -2. This has been approached in the case of absorption by carbon.

LXXVII. The Ratio between Uranium and Radium in Minerals. II. By Ruth PirreI, B.Sc, and Frederick Sodvy, M.A., F.R.S.*

TN a previous paper on this subject (Phil. Mag. 1910 [6] $1 \mathrm{xx}$. p. 345), a short account was given of the determination of the ratio of radium to uranium in Ceylon thorianite and a specimen of Portuguese autunite. The preliminiry results went to confirm those of Mlle. Gleditsch (Compt. liend. 1909, cxlviii. p. 1451 ; cxlix. p. 267) in that the ratio in autunite was found to be considerably lower than in pitchblende ; but the results with thorianite were not equally conclusive. Only one specimen of thorianite was compared with the old pitchblende standards prepared some years ago. Further investigations with several different specimens of thorianite, pitchblende, and autunite were therefore carried out on the same lines.

Uranium Analysis. - The methods of e-timating the uranium in thorianite and autunite have already been described. In the case of the pitchblendes the mineral was first dissolved in nitric acid, the solution diluted, filtered, evaporated to dryness, the residue dissolved in hydrochloric acid, treated with sulphuretted hydrogen and filtered. The filtrate, after heating and oxidizing, was poured into a mixture of ammonium hydrate, sulphide, and carbonate, corked, and left over night. The filtrate from this precipitate was heated, acidified by nitric acid, and the uranium precipitated by microcosmic salt and sodium thiosulphate in presence of acetic acid. The precipitate was ignited in a porcelain crucible and weighed in the form of a green compound of constant composition. It was then converted, by means of a few drops of strong nitric acid, into uranium pyrophosphate and weighed again after ignition at a dull red heat (Brearley's 'Analytical Chemistry of Uranium,'p. 7). In some cases Patera's Method (Fresenius, 'Quantitative Analysis,' vol. ii. p. 310) was employed, or a modification of it in which, instead of the uranium being weighed as sodium uranate, it was, after separation by

* Communicated by the Authors. 
means of sodium carbonate, estimated as pyrophosphate as before.

lable I. contains the results of the estimation of uranium in the various minerals. The thorianites were all specimens of (eylon thorianite. "Th $\mathrm{I}$, Th $\mathrm{I}$ a, 'Th $\mathrm{I} b$ " were from the same sample of the variety richest in uranium and containing a small residne (3 per cent.) iusoluble in acid. " $\mathrm{Th} \mathrm{X}_{2}$ " was a poor specimen of the mineral, and contained nearly 24 per cent. of insoluble material. "Th (CC" and "Th $\mathrm{E}$ " were specimens of mixtures of the two varieties (which differ chiefly in their respective high or low percentage of uranium). The pitchblende "PI" was a specimen from Joachimsthal which contained comparatively little uranium and proved troublesome in the analysis and unsatisfactory in the results. The other ("J.P.A " and "J.P.B") was a picked

TABIE I.

\begin{tabular}{|c|c|c|c|c|c|c|}
\hline & \multicolumn{6}{|c|}{ Percentuge of Uranium. } \\
\hline & (1) & (2) & (3) & (4) & (5) & Mean. \\
\hline 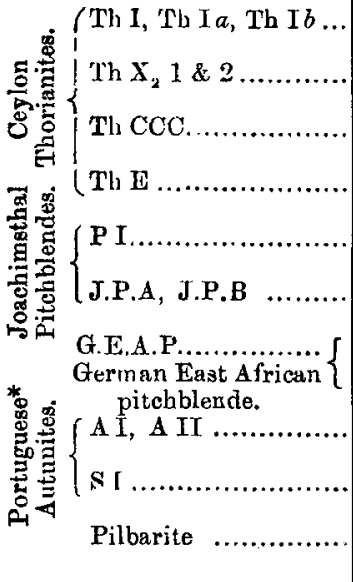 & $\begin{array}{r}20 \cdot 80 a \\
20 \cdot 56 b \\
949 a \\
9 \cdot 39 b \\
13 \cdot 02 a \\
13 \cdot 20 b \\
17 \cdot 21 a \\
17 \cdot 93 b \\
33 \cdot 35 c \\
33 \cdot 57 d \\
62 \cdot 37 a \\
61 \cdot 39 b \\
72 \cdot 30 c \\
70 \cdot 31 d \\
20 \cdot 04 a \\
47 \cdot 82 a \\
49 \cdot 30 b \\
20 \cdot 45 a \\
20 \cdot 85 b\end{array}$ & $\begin{array}{l}20 \cdot 11 c \\
20 \cdot 28 d \\
10.71 d \\
1 \ldots \ldots \\
1404 a \\
14 \cdot 14 b \\
17.42 a \\
17 \cdot 95 b \\
28 \cdot 06 c \\
28 \cdot 22 d \\
60.73 a \\
59 \cdot 98 b \\
\} \ldots \ldots\end{array}$ & $\begin{array}{l}19 \cdot 86 c \\
19 \cdot 99 d \\
10 \cdot 40 d \\
\ldots \ldots \\
13.44 a \\
13 \cdot 82 b \\
\} \ldots \ldots \\
30 \cdot 81 d \\
6 \ldots .6 \\
\ldots \ldots \ldots \\
\ldots \ldots \\
19 \cdot 54 d \\
\} \ldots \ldots\end{array}$ & $\begin{array}{l}19 \cdot 32 c \\
19.74 d \\
\{\ldots \ldots \\
\ldots \ldots \\
\ldots \ldots \\
34 \cdot 99 a \\
34 \cdot 71 b \\
61 \cdot 34 a \\
61 \cdot 01 b \\
\ldots \ldots\end{array}$ & $\begin{array}{c}19 \cdot 80 c \\
20 \cdot 15 d \\
\ldots \ldots \\
\ldots \ldots \\
\ldots \ldots \\
31 \cdot 20 e \\
\ldots \ldots \\
\ldots \ldots . \\
\ldots \ldots\end{array}$ & $\begin{array}{c}\begin{array}{c}17 \cdot 62 \\
31 \cdot 86 \\
61 \cdot 23 \\
71 \cdot 3\end{array}\end{array}$ \\
\hline
\end{tabular}

* The other autunites referred to in Tables II. and 1II. were used in connexion with otber work (Le Radium, 1910, vii. p. 295), and details of the uranium analysis need not be given.

$a$ denotes that the uranium was weighed as the green compound before conversion into pyrophosphate.

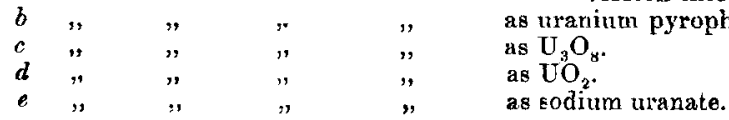


specimen of Joachimstlal pitchblende containing a much larger proportion of uranium. "G.F.A.P." was a German East-Atrican pitchblende. The autunites were all specimens of Portuguese autunite. A specimen of the new mineral pilbarite was obtained from Mr. Simpson of the West Australian Government Survey. It is described in the 'Australian Mining Standard,' 7/9/10 (Chem. News, 1910, cii. p. 283).

Method of Estimation of Radium.-The radium was estimated in the solution of the mineral by the emanation method. The apparatus used was at first (series A) that described by one of us (Phil. Mag, 1909 [6] xviii. p. 846). Later a new apparatus was employed with a microscope of about four times less magnifying power. With this instrument the leaf was charged positively instead of negatively, and was not kept charged during the period of three hours preceding the measurements (series $B$ and $C$ ). A period of about three months elapsed between series $B$ and $C$. In all twenty-seven radium preparations were used including the six old pitchblende standards already described (loc. cit.), representing twelve different minerals. These were prepared by dissolving quantities of minerals which could be accurately weighed, and taking a known fraction by weight of the solution.

Table II. shows the results. Column (1) gives the designation of the preparation, those bracketed being of the same specimen of the same mineral. Column (2) gives the number of milligrams of uranium in the preparation. Columns $3,4,5$ give the number of divisions of leak of the electroscope-leaf per minute in the three respective sets of observations, and $6,7,8$ the same per milligram of uranium present.

The old standards I. to VI. had existed for nearly four years, and comparing the results in Table II. with the deterininations previously published (loc. cit.) made at the time of preparation, the variations among the standards are rather larger than they were initially, but do not show any certain influence of age. "R I" and "R II" were made up on June 16, 1910, from a solution of radium bromide obtained from Professor Rutherford, and described by him as containing $1570 \times 10^{-12}$ gram of radium. The RutherfordBoltwood ratio is assumed in stating the quantity of uranium in these $\left(3.4 \times 10^{-7}\right.$ gram of radium per gram of uranium). 
TABLE II.

\begin{tabular}{|c|c|c|c|c|c|c|c|}
\hline \multirow{2}{*}{ Specimen. } & \multirow{2}{*}{$\begin{array}{c}\text { Uranium } \\
\text { (milligrms) }\end{array}$} & \multicolumn{3}{|c|}{ Leak (divisions per $1 \mathrm{~min}$.). } & \multicolumn{3}{|c|}{$\begin{array}{l}\text { Lenk per } 1 \text { min. per } 1 \text { milli- } \\
\text { gram Uranium. }\end{array}$} \\
\hline & & A. & B. & C. & A. & B. & C. \\
\hline 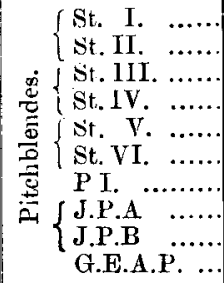 & $\begin{array}{l}\cdot 308 \\
1 \cdot 49 \\
\cdot 696 \\
666 \\
\cdot 149 \\
\cdot 74 \\
.395 \\
\cdot 171 \\
.3539 \\
\cdot 6534\end{array}$ & $\begin{array}{l}20 \cdot 28 \\
\ldots \ldots . \\
\ldots \ldots . \\
\ldots \ldots \\
9 \cdot 70 \\
\ldots \ldots . \\
23.55 \\
\ldots \ldots . \\
\ldots \ldots \\
49 \cdot 64\end{array}$ & $\begin{array}{r}19 \cdot 72 \\
9 \cdot 56 \\
86 \cdot 80 \\
\ldots \ldots . \\
9 \cdot 75 \\
4 \cdot 91 \\
2.25 \\
4.66 \\
10.39\end{array}$ & $\begin{array}{r}3 \cdot 99 \\
20 \cdot 88 \\
9 \cdot 83 \\
\ldots \ldots \\
1.80 \\
10 \cdot 01 \\
\overline{0} \cdot 02 \\
\ldots \ldots \\
5 \cdot 00 \\
10 \cdot 56\end{array}$ & $\begin{array}{l}65 \cdot 83 \\
\ldots \ldots . \\
\ldots \ldots . . \\
\ldots \ldots . \\
65 \cdot 10 \\
\ldots \ldots . . \\
\ldots \ldots .6 \\
\ldots \ldots . . \\
7597\end{array}$ & $\begin{array}{l}13 \cdot 23 \\
13 \cdot 74 \\
13 \cdot 02 \\
\dddot{13} \cdot \% \\
12 \cdot 23 \\
13 \cdot 43 \\
13 \cdot 17 \\
15 \cdot 90\end{array}$ & $\begin{array}{c}{[12 \cdot 98]} \\
14 \cdot 23 \\
14 \cdot 14 \\
\ldots \ldots \\
{[12 \cdot 10]} \\
13 \cdot 53 \\
1271 \\
\ldots \ldots \\
14 \cdot 13 \\
16 \cdot 16\end{array}$ \\
\hline $\begin{array}{l}\mathbf{R I} \\
\mathrm{RII} . .\end{array}$ & $\begin{array}{r}.2077 \\
1.0066\end{array}$ & $\begin{array}{l}14 \cdot 80 \\
72: 20\end{array}$ & $\begin{array}{r}2 \cdot 61 \\
14 \cdot 25\end{array}$ & $\begin{array}{r}2 \cdot 71 \\
14.85\end{array}$ & $\begin{array}{l}71 \cdot 25 \\
71 \cdot 78\end{array}$ & $\begin{array}{c}{[12 \cdot 54]} \\
14 \cdot 17\end{array}$ & $\left.\begin{array}{l}{[13 \cdot 07]} \\
14.77\end{array}\right]$ \\
\hline 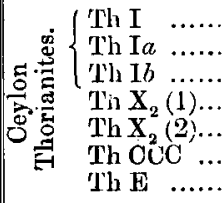 & $\begin{array}{l}\cdot 6103 \\
3 \cdot 027 \\
1 \cdot 926 \\
8 \cdot 4103 \\
1 \cdot 03 \\
\cdot 3475 \\
3 \cdot 168\end{array}$ & 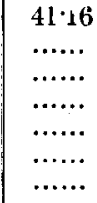 & $\begin{array}{r}8 \cdot 31 \\
43 \cdot 65 \\
\ldots \ldots \\
111 \cdot 5 \\
\cdots \ldots \\
4 \cdot 56\end{array}$ & $\begin{array}{r}8 \cdot 63 \\
43 \cdot 64 \\
27 \cdot 88 \\
\ldots \ldots . \\
13 \cdot 91 \\
4 \cdot 68 \\
41 \cdot 64\end{array}$ & $\begin{array}{l}67 \cdot 44 \\
\ldots \ldots . . \\
\ldots \ldots . . \\
\ldots \ldots . . \\
\ldots \ldots . . \\
\ldots \ldots . . \\
\ldots \ldots .\end{array}$ & $\begin{array}{l}14 \cdot 43 \\
14 \cdot 42 \\
\ldots \ldots . \\
13 \cdot 25 \\
\ldots \ldots . \\
13 \cdot 14 \\
\ldots \ldots .\end{array}$ & $\begin{array}{l}14 \cdot 6.2 \\
14 \cdot 41 \\
14 \cdot 47 \\
\ldots \ldots \\
13 \cdot 51 \\
13 \cdot 46 \\
13 \cdot 14\end{array}$ \\
\hline 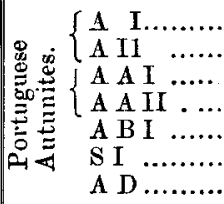 & $\begin{array}{c}\cdot 834 \\
.92 \\
.568 \\
1.69 \\
\cdot 562 \\
2 \cdot 531 \\
1 \cdot 265\end{array}$ & $\begin{array}{l}24 \cdot 28 \\
26.22 \\
26 \cdot 18 \\
\ldots \ldots \\
16 \cdot 24 \\
\ldots \ldots . . \\
\ldots \ldots .\end{array}$ & $\begin{array}{r}512 \\
4 \cdot 42 \\
5 \cdot 33 \\
16 \cdot 29 \\
3 \cdot 29 \\
\ldots \ldots . . \\
\ldots \ldots .\end{array}$ & $\begin{array}{c}\ldots \ldots . \\
\ldots \ldots \\
\cdots \cdots \\
\ldots \ldots . \\
\ldots \ldots . \\
8 \cdot 43 \\
12 \cdot 92\end{array}$ & $\begin{array}{l}29 \cdot 1 \\
28 \cdot 5 \\
46 \cdot 1 \\
\ldots \ldots . \\
28 \cdot 9 \\
\ldots \ldots . .\end{array}$ & $\begin{array}{l}6 \cdot 14 \\
4 \cdot 80 \\
9 \cdot 39 \\
9 \cdot 63 \\
5 \cdot 85 \\
\ldots \ldots . \\
\cdots \cdots . .\end{array}$ & $\begin{array}{c}\ldots \\
\ldots \\
\ldots \\
\cdots \\
\ldots \\
3 \cdot 33 \\
10 \cdot 22\end{array}$ \\
\hline Pilbarite ... & $1 \cdot 359$ & ....... & ...... & $12 \cdot 10$ & ....... & $\ldots \ldots$ & $8 \cdot 90$ \\
\hline
\end{tabular}

Discussion of Results.-In interpreting the results of Table II. it must be remembered that the determinations have not all equal weight. The specimens on which the A series of measurements was performed contained as a rule too small quantities of radium to give the best results with the less sensitive electroscope and method employed in the $\mathrm{B}$ and $\mathrm{C}$ series. The measurements of Table II. enclosed in square brackets may be at once eliminated from further consideration on this account. In addition many of the solutions had been prepared a considerable time, and may have undergone changes by keeping. Three months elapsed between the measurements in the $B$ and $C$ series, and it is evident from the Table that the sensitiveness of the instrument had somewhat increased in the interval, as has been observed before with the old instrument. 
656 Miss Ruth Pirret and Mr. F. Soddy on the

The first thing is to reduce the three series of measurements given in the last three columns of Table II. to a common standard. This has been done by taking first the mean value in each of the three series for each of the minerals, except the autunites, and then taking the mean of these means. The result is, in divisions per milligram of uranium :-
A $68 \cdot 00$,
B $13 \cdot 79$,
C $14 \cdot 24$.

Hence to reduce all the determinations to the same standard as the ( $)$ series, the A series must be multiplied by the factor $0 \cdot 212$, and the $B$ series by $1 \cdot 033$. This has been done in Table III.

\section{Table III.}

\begin{tabular}{|c|c|c|c|c|}
\hline & \multicolumn{4}{|c|}{$\begin{array}{c}\text { Divisions per milligram of Uranium } \\
\text { (reduced values). }\end{array}$} \\
\hline & $A($ cor. $)$ & $\mathrm{B}$ (cor.). & c. & Meank. \\
\hline 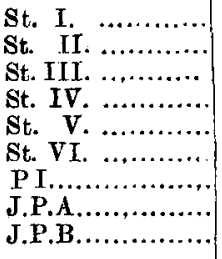 & $\begin{array}{l}13 \cdot 95 \\
\ldots \ldots . \\
\ldots \ldots . . \\
\ldots \ldots . \\
13.82 \\
\ldots \ldots . \\
1264 \\
\ldots \ldots . \\
\ldots \ldots .\end{array}$ & 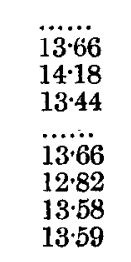 & $\begin{array}{l}14 \cdot 23 \\
14 \cdot 14 \\
\ldots \ldots . . \\
\ldots \ldots \\
13 \cdot 53 \\
12 \cdot 71 \\
\ldots \ldots . . \\
14 \cdot 13\end{array}$ & $\begin{array}{l}12.72 \\
13.77\end{array}$ \\
\hline G.E.A.P. ......... & $16 \cdot 10$ & $16 \cdot 41$ & $16 \cdot 16$ & $16 \cdot 22$ \\
\hline $\begin{array}{l}\mathrm{R} \\
\mathrm{I} \\
\mathrm{R} \text { II }\end{array}$ & $\begin{array}{l}15 \cdot 10 \\
15 \cdot 20\end{array}$ & $\dddot{14} 62$ & $14 \cdot 77$ & $14 \cdot 90$ \\
\hline 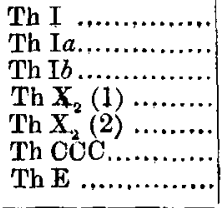 & 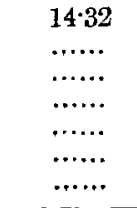 & $\begin{array}{l}14 \cdot 89 \\
14 \cdot 88 \\
\ldots \ldots . \\
13 \cdot 68 \\
\ldots \ldots . \\
13 \cdot 56 \\
\ldots \ldots\end{array}$ & $\begin{array}{l}14 \cdot 62 \\
14 \cdot 41 \\
14 \cdot 47 \\
\dddot{13} \cdot 51 \\
13 \cdot 46 \\
13 \cdot 14\end{array}$ & $\begin{array}{l}14 \cdot 60 \\
13 \cdot 55\end{array}$ \\
\hline 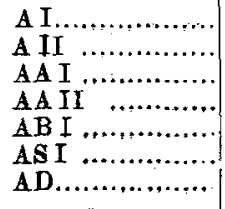 & $\begin{array}{c}6 \cdot 20 \\
6 \cdot 05 \\
9 \cdot 80 \\
\ldots \cdots \\
6 \cdot 12 \\
\cdots \cdots \\
\cdots \cdots\end{array}$ & $\begin{array}{l}6.32 \\
4.96 \\
9 \cdot 68 \\
9 \cdot 94 \\
6 \cdot 03 \\
\cdots \ldots . . \\
\cdots \ldots . .\end{array}$ & $\begin{array}{c}\ldots \ldots . . \\
\ldots \ldots . . \\
\ldots \ldots . . \\
\ldots \ldots \ldots \\
\ldots \ldots \cdot \cdot \\
3 \cdot 33 \\
10 \cdot 22\end{array}$ & $7 \cdot 15$ \\
\hline Pilbarite .......... & $\cdots \cdots$ & ...... & $8 \cdot 90$ & \\
\hline
\end{tabular}


Dealing first with the pitchblendes, the mean results for the old stundards are :-
A 13.83,
B 13.74,
C 13.97,

which gives a mean result for this nineral of $13 \cdot 85$. The mean of the three determinations for the mineral "J.P.A" and "J.P.B" is $13 \cdot 77$. So that from these two results the mean value 13.8 may be taken with considerable confidence as representiug Joachimsthal pitchblende. The specimen P I, giving a mean result of $12 \cdot 72$, must be rejected, for, as will be seen from Table I.. its uranium analysis is far from satisfactory. Indeed this mineral proved most troublesome to analyse, the uranium content being low and the proportion of foreign constituents high. 'The mean of the fonr determinations with Rutherford's radium standard is 14.9 ; so that, if this is taken as the primary standard, the ratio of radium to uranium in Joachimsthal pitchblende is $3 \cdot 15\left(\times 10^{-7}\right)$. The original value given by Rutherford and Boltwood was $3 \cdot 8$, which was lowered subsequently to $3 \cdot 4$ owing to an error in the uranium analysis (Boltwood, Am. Journ. Sci. 1911, xxv. p. 296). The radium solution provided by Professor Rutherford was part of the original employed by these investigators; so that, assuming the solution has not changed since its preparation, our results indicate that the corrected value is still somewhat high. The value we have arrived at, $3 \cdot 15\left(\times 10^{-7}\right)$, is in good agreement with the following results of Mlle. Gleditsch, obtained with Mme. Curie's standards of radium (Mme. Curie, Radioactivité, ii. p. 441):-St. Joachimsthal pitchblende $3 \cdot 21$, Norwegian Clè reite $3 \cdot 23$, Bröggerite $3 \cdot 22$, Portuguese chalcolite $3 \cdot 24$.

Dealing now with the thorianites, the Table shows that although the first specimen investigated, "Th I," as recorded in the last paper, gives an undoubtedly higher value than Joachimsthal pitchblende, it is alone of those examined in this respect. Five different uranium analyses and six estimations of the radium in three solutions of this mineral give the mean result $14 \cdot 6$, which is about 6 per cent. higher than that for Joachimsthal pitchblende. Even if the highest uranium result and the lowest radium result are compared, the value arrived at would still be as high as the mean for Joachimsthal pitchblende. But the other thorianites examined give an entirely different result. The mean five determinations on the three minerals is 13.47 . Omitting "Th E," for which only one determination has so far been done. the mean is 13.55 . Hence the later results have not confirmed 


\section{Ratio between Uranium and Radium in Minerals.}

these of Mlle. Gleditsch that the ratio for thorianite is 20 per cent. higher than for pitchblende. It is interesting to notice that investigations published subsequently to Mlle. Gleditsch's work (Marckwald, Ber. Chem. Ges. 1910, xliii. p. 3420 ; Soddy, Trans. Chem. Soc. 1911, xcix. p. 72) show that in separating the radium she must also have separated the mesothorium quantitatively from the thorianite, though this does not account for her results.

We are inclined to ascribe the undoubtedly high value obtained for "Th I" to contamination with radium before it came into our hands. All the other specimens were samples of large quantities purchased direct from the importers, but "Th I" was obtained from a retail dealer who handles radium preparations and sells spinthariscopes. We attach no importance to the high result for the single specimen of German East-African pitchblende, as the same doubt arises. It came to us through Mr. Russell from Prof. Marckwald's laboratory, where chemical work on radium has long been carried on.

With regard to the autunites, all of which came from various mines in Portugal, the values range from that of "A D," which has 74 per cent. of the equilibrium amount, to that of "A S," which has only 24 per cent. and is the lowest yet recorded, that described by Mr. Russell (Nature, Ang. 25, 1910) from Autun, France, having 27 per cent. It is interesting to note that both these specimens "A D" and "AS" were from the same property (compare Ann. Reports, (hem. Soc. 1910, vii. p. 264). The pilbarite is also low (64 per cent.), but the mineral, described as probably a hydrous pseudomorph of an anhydrous parent mineral, is evidently much altered.

The main point at issue, that possibly the life-period of ionium is sufficiently extended to cause the equilibrium ratio of radium to uranium to be less in a geologically recent mineral like Joachimsthal pitchblende than in an ancient mineral like thorianite, although no doubt still an open one, certainly receives no support from these measurements.

Physical Ohemical Laboratory, University of Glasgow. March 22nd, 1911. 